\title{
Selective Separation of Chromium Species from Soils by Single-Step Extraction Methods: a Critical Appraisal
}

\author{
Barbara Leśniewska • Marta Gontarska • \\ Beata Godlewska-Żyłkiewicz
}

Received: 20 March 2017 / Accepted: 27 June 2017 / Published online: 13 July 2017

(C) The Author(s) 2017. This article is an open access publication

\begin{abstract}
A critical appraisal of single-step extraction procedures of chromium species from soil was done in terms of their selectivity towards $\mathrm{Cr}$ (III) and $\mathrm{Cr}$ (VI) species. Samples of natural mineral and organic soil and samples of soil enriched with different chromium compounds of various solubility (in liquid or solid form) were used to simulate contamination of soil by liquid and solid wastes. The efficiency of extraction of $\mathrm{Cr}$ (III) and $\mathrm{Cr}(\mathrm{VI})$ species with various reagents, e.g. acetic acid, chelating agents (EDTA, DTPA) or inorganic salts (phosphates and carbonates), was evaluated on the basis of recovery results obtained for enriched samples. None of used reagents allow for quantitative extraction of added $\mathrm{Cr}$ (III) form. Procedures based on extraction of soil with $\mathrm{Na}_{2} \mathrm{CO}_{3}$ at room and elevated temperature $\left(90-95^{\circ} \mathrm{C}\right.$ ) were suitable for extraction of $\mathrm{Cr}(\mathrm{VI})$ species from mineral soil, whereas for organic soil, the procedure based on extraction with $\mathrm{Na}_{2} \mathrm{CO}_{3}$ at room temperature was recommended. The developed extraction procedures were validated using certified reference material (CRM 041 soil) and applied for analysis of contaminated soil samples. The studies showed that the physical state of waste, initial form and oxidation state of chromium and soil properties influenced the final chromium species and their mobility in soil, which have an impact on contamination of environment. The analysis of contaminated soil samples from a tannery
\end{abstract}

B. Leśniewska $(\bowtie) \cdot$ M. Gontarska •

B. Godlewska-Żyłkiewicz

Institute of Chemistry, University of Bialystok, K. Ciołkowskiego

$1 \mathrm{~K}, 15-245$ Bialystok, Poland

e-mail: blesniew@uwb.edu.pl area showed that the share of $\mathrm{Cr}(\mathrm{VI})$ was very low (only $0.8-4.5 \%$ ) despite the high total content of chromium, which confirmed that chromium was present in immobile forms.

Keywords Chromium(VI) · Mobility of Cr(III) and $\mathrm{Cr}(\mathrm{VI}) \cdot$ Interconversion of chromium species · ETAAS . Environmental analysis

\section{Introduction}

Chromium occurs in the environment mostly in two species, i.e. as a trivalent (III) and hexavalent (VI) form. Chromium has been proposed as an essential element; however, recent studies suggest that it should be removed from the list of essential trace elements. It was shown that $\mathrm{Cr}(\mathrm{III})$ plays a key role in chromium allergy and causes DNA damage in cell-culture systems (Vincent 2010). Cr(VI) (chromate) is known to be a genotoxic carcinogen due to the redox reactions that take place in cells which generate $\mathrm{Cr}(\mathrm{V})$-1,2-diolato species (Chellan and Sadler 2015).

Chromium can enter the environment both from natural and anthropogenic sources, e.g. via electroplating, leather tanning and the textile industries (Avudainayagam et al. 2003; Johnson et al. 2006; Unceta et al. 2010; Dhal et al. 2013). Anthropogenic emission of chromium to the atmosphere is substantial and was estimated at $336 \mathrm{t}$ in the European Union in 2013 (EEA Technical report 2015), 2700-2900 $\mathrm{t}$ in the USA and 21,000 $\mathrm{t}$ in China in 2009 (Cheng et al. 2014). Chromium released into the 
atmosphere is carried in the air as particles or dust. It may be transported over long distances by the wind, but finally settles on the soil. Rain will also remove chromium particles from the atmosphere and deposit them in the ground, thus contaminating the soil. The disposal of chromiumcontaining commercial products (e.g. some inks, paints and paper, rubber and composite floor coverings or toner powders used in copying machines) and coal fly ash from electric utilities and other industries are major sources of chromium releases into the soil (Barceloux 1999; Metze et al. 2005; Dhal et al. 2013). Solid waste and slag produced during chromate manufacturing processes as well as agricultural and food wastes, when disposed of improperly in landfills, can be another potential source of chromium exposure (Kimbrough et al. 1999; Barceloux 1999).

The Canadian Soil Quality Guidelines for the protection of human health recommend a maximum content for hexavalent chromium and total chromium in agricultural and residential land as 0.4 and $64 \mathrm{mg} \mathrm{kg}{ }^{-1}$, respectively (Canadian Environmental Quality Guidelines 2001). The Swedish Guidelines (Guidelines for Polluted Soils 2002) suggest maximum concentrations for the most sensitive type of land use at 5 and $120 \mathrm{mg} \mathrm{kg}^{-1}$ for $\mathrm{Cr}(\mathrm{VI})$ and $\mathrm{Cr}(\mathrm{III})$, respectively. In Italy, the highest permissible $\mathrm{Cr}(\mathrm{VI})$ concentrations in soil are 2 and $15 \mathrm{mg} \mathrm{kg}^{-1}$, respectively, depending on the type of exploitation, i.e. parkland or industrial (Decreto Ministeriale n.471 1999; Pettine and Capri 2005a). In Poland, the limit for total chromium in agricultural and residential land was set at $150 \mathrm{mg} \mathrm{kg}^{-1}$ (Ordinance of the Minister of Environment of Poland 2016). The content of $\mathrm{Cr}_{\mathrm{Tot}}$ and $\mathrm{Cr}(\mathrm{VI})$ in contaminated soil can reach a level of several grammes per-kilogramme (Dhal et al. 2013).

The behaviour of metals in soil and uptake by plants is controlled by element speciation and by soil properties, such as $\mathrm{pH}$, particle size, cationexchange capacity, content of organic matter, content and type of clay minerals and $\mathrm{Al}, \mathrm{Fe}$ and $\mathrm{Mn}$ oxides, redox potential and microbiological activity (Kotaś and Stasicka 2000; Dhal et al. 2013; Krasnodębska-Ostręga et al. 2009; Paldyna et al. 2013). Chromium(III) in soil is mostly present as insoluble chromium(III) hydroxide and tends to be adsorbed on the soil surface in a $\mathrm{pH}$ range of 4-8. The solubility of $\mathrm{Cr}(\mathrm{III})$ in soil and its mobility may increase due to the formation of soluble complexes with organic matter in soil, e.g. citric acid, diethylenetriaminepentaacetic acid (DTPA) and fulvic acid. Hence, a lower soil $\mathrm{pH}$ potentially facilitates complexation (Avudainayagam et al. 2003; Kotaś and Stasicka 2000). The most mobile forms of $\mathrm{Cr}(\mathrm{VI})$ in soil are $\mathrm{CrO}_{4}{ }^{2-}$ and $\mathrm{HCrO}_{4}{ }^{-}$ions, but insoluble species such as $\mathrm{BaCrO}_{4}$ and $\mathrm{PbCrO}_{4}$ may also be present (Kotaś and Stasicka 2000). Oxidation and reduction of chromium species in soil can take place simultaneously. Cr(VI) may react with many inorganic reductants such as $\mathrm{Fe}(\mathrm{II})$ and sulphide as well as with a number of organic compounds, including carboxylic and hydroxycarboxylic acids, aldehydes, phenols or fulvic acid (Eckert et al. 1990; Brose and James 2010). Moreover, several microorganisms possess the ability to reduce Cr(VI) (Brose and James 2010; Dhal et al. 2013). In soil containing manganese oxides, $\mathrm{Cr}$ (III) can be oxidised to $\mathrm{Cr}(\mathrm{VI})$, especially at high $\mathrm{pH}$ values (Dhal et al. 2013).

Various extraction procedures have been proposed in order to determine chromium(VI) species in solid environmental samples. The extraction conditions have to be carefully chosen as the leaching process may lead to interconversion of $\mathrm{Cr}$ species. The extraction solutions can be divided into the following groups: (a) acids at various concentrations, e.g. $0.43 \mathrm{~mol} \mathrm{~L}^{-1}$ acetic acid $\left(\mathrm{CH}_{3} \mathrm{COOH}\right)$ (Lillengen and Wibetoe 2002), (b) buffered salts, e.g. ammonium acetate $\left(\mathrm{NH}_{4} \mathrm{OAc}\right)$ (MoralesMuñoz et al. 2004) and $\mathrm{K}_{2} \mathrm{HPO}_{4}$ (Rüdel and Terytze 1999; James et al. 1995), (c) neutral salts such as $\mathrm{CaCl}_{2}$ (Béni et al. 2007), $\mathrm{Na}_{3} \mathrm{PO}_{4}$ (Mandiwana 2008) or $\mathrm{Na}_{2} \mathrm{CO}_{3}$ (Panichev et al. 2003; Elci et al. 2010), (d) chelating agents, e.g. ethylenediaminetetraacetic acid (EDTA) (Lillengen and Wibetoe 2002; Korolczuk and Grabarczyk 2005), DTPA (Grabarczyk et al. 2006) and $\mathrm{S}, \mathrm{S}$-ethylenediamine-N, $\mathrm{N}^{\prime}$-trisodium salt (EDDS) (Grabarczyk 2008) and (e) other extractants (Gitet et al. 2013) proposed for routine soil testing. Some of these procedures have been designed in order to distinguish between soluble, exchangeable and slightly soluble forms of chromium(VI).

Alkaline media have been suggested for selective extraction of slightly soluble $\mathrm{Cr}(\mathrm{VI})$, as in such an environment, $\mathrm{Cr}(\mathrm{VI})$ is stable in the solution while $\mathrm{Cr}$ (III) species form insoluble hydroxides or carbonates. Insoluble forms of $\mathrm{Cr}(\mathrm{VI})$ are often extracted with suitable chelating agents by forming soluble complexes of cations. At the same time, $\mathrm{Cr}(\mathrm{VI})$ is transferred into the solution as a soluble salt. The most recommended method for determining $\mathrm{Cr}(\mathrm{VI})$ in solid matrices is the US 
EPA method 3060A, which was designed and validated by Vitale et al. $(1994,1995)$. In this method, a hot (90$\left.95^{\circ} \mathrm{C}\right) 0.28 \mathrm{~mol} \mathrm{~L}^{-1} \mathrm{Na}_{2} \mathrm{CO}_{3}$ solution in $0.5 \mathrm{~mol} \mathrm{~L}^{-1}$ $\mathrm{NaOH}$ is used to extract the "total" amount of $\mathrm{Cr}(\mathrm{VI})$ from the soil and sediments. However, the presence of the reducing compounds results in an underestimated concentration of $\mathrm{Cr}(\mathrm{VI})$ in the extraction solution (Malherbe et al. 2011). Conversely, some authors have observed partial oxidation of soluble Cr(III) and a positive error in Cr(VI) determination (Huo et al. 1998; Huo and Kingston 2000). A brief description of these procedures, their effectiveness and application for solid samples is presented in Table 1.

It should be noted that the extraction procedures are not always selective for $\mathrm{Cr}(\mathrm{VI})$, as differentiation between oxidised and reduced $\mathrm{Cr}$ species may be obtained by using specific analytical methods, e.g. the diphenylcarbazide (DPC) method for $\mathrm{Cr}(\mathrm{VI})$. However, many papers have indicated interference in spectrophotometric chromium(VI) detection caused by the presence of other metal ions, e.g. $\mathrm{Cu}(\mathrm{II}), \mathrm{Mo}(\mathrm{VI}), \mathrm{Fe}(\mathrm{III}), \mathrm{V}(\mathrm{V})$ and $\mathrm{Hg}(\mathrm{II})$, and humic acids released from the soil (Pettine and Capri 2005b). Determining the chromium via a specific spectroanalytic detection technique, e.g. atomic absorption spectrometry, provides more accurate results and a lower detection limit. However, in this case, selectivity of the extraction procedures towards $\mathrm{Cr}(\mathrm{VI})$ and $\mathrm{Cr}(\mathrm{III})$ species should be assessed.

The aim of this work was to appraise the procedures originally proposed for the leaching of chromium(VI) species from solid samples in terms of their selectivity towards trivalent and hexavalent chromium species. For this reason, mineral and organic soil was spiked with soluble and slightly soluble chromium compounds $\left(\mathrm{CrCl}_{3} 6 \mathrm{H}_{2} \mathrm{O}, \mathrm{K}_{2} \mathrm{Cr}_{2} \mathrm{O}_{7}, \mathrm{BaCrO}_{4}\right)$. The spikes were dosed in liquid and solid forms in order to evaluate the mobility of chromium from waste disposal sites. The recoveries of chromium obtained after treating the soil with seven extraction procedures were controlled by electrothermal atomic absorption spectrometry (ETAAS) and compared in order to select the most suitable procedure for extraction of $\mathrm{Cr}(\mathrm{VI})$ and $\mathrm{Cr}$ (III) species. The trueness of the procedure proposed for selective extraction of $\mathrm{Cr}(\mathrm{VI})$ was verified in an analysis of certified reference material of soil (CRM 041). The chosen extraction procedures were applied to determine $\mathrm{Cr}(\mathrm{VI})$ in soils sampled in the Podlasie Province (Poland).

\section{Material and Methods}

\subsection{Instrumentation}

A Solaar M6 (Thermo Electron Corporation, UK) atomic absorption spectrometer equipped with a Zeemaneffect background correction system and an electrothermal atomizer (ELC graphite tubes) was used for chromium determination. A chromium hollow cathode lamp (Photron, Australia) was operated at $15 \mathrm{~mA}$. The measurements were done at $\lambda=357.9 \mathrm{~nm}$ with a spectral bandpass of $0.5 \mathrm{~nm}$. The following optimised heating programme was used to determine chromium in the soil extracts: drying at $110^{\circ} \mathrm{C}$ for $15 \mathrm{~s}$, ashing at $1200^{\circ} \mathrm{C}$ or $1650{ }^{\circ} \mathrm{C}$ for $8 \mathrm{~s}$, and atomisation at $2600{ }^{\circ} \mathrm{C}$ for $3 \mathrm{~s}$. A temperature of $1650{ }^{\circ} \mathrm{C}$ was used to ash extracts containing $\mathrm{K}_{2} \mathrm{HPO}_{4}$ in the presence of $\mathrm{Mg}\left(\mathrm{NO}_{3}\right)_{2}(10 \mu \mathrm{L}$ of $\left.10 \mu \mathrm{g} \mathrm{mL}^{-1}, 0.1 \mu \mathrm{g}\right)$ as a chemical modifier. An inoLab pH Level 1 (WTW, Germany) pH meter equipped with a SenTix 21 electrode (WTW, Germany) was used for the pH measurements. A Shimadzu SSM-5000A TOC Analyser was used to determine the carbon content in the soil by catalytically aided combustion oxidation method. A ball mill (KM 1 type K142, MLW, Poland) was used for soil grinding.

\subsection{Reagents}

Stock solutions $\left(20 \mathrm{~g} \mathrm{~L}^{-1}\right)$ of $\mathrm{Cr}(\mathrm{III})$ as $\mathrm{CrCl}_{3}$ (Merck, Germany) and (1.001 $\left.\mathrm{g} \mathrm{L}^{-1}\right)$ of $\mathrm{Cr}(\mathrm{VI})$ as $\mathrm{K}_{2} \mathrm{Cr}_{2} \mathrm{O}_{7}$ (Sigma-Aldrich, Germany) were used. Working standard solutions of chromium were prepared daily by appropriate dilution of the stock standards. Reagents used for chromium extraction: $\mathrm{K}_{2} \mathrm{HPO}_{4}, \mathrm{Na}_{3} \mathrm{PO}_{4}$, $\mathrm{Na}_{2} \mathrm{CO}_{3}$ and EDTA as well as reagents used for spiking of soil $\mathrm{CrCl}_{3} 6 \mathrm{H}_{2} \mathrm{O}, \mathrm{K}_{2} \mathrm{Cr}_{2} \mathrm{O}_{7}$ and $\mathrm{BaCrO}_{4}$ were obtained from $\mathrm{POCh}$ (Poland). Acetic acid and $\mathrm{KCl}$ were obtained from Chempur (Poland), and DTPA was obtained from Sigma-Aldrich (Germany). Deionised water was obtained from the Milli-Q water purification system (Millipore, USA).

\subsection{Samples and Procedures}

\subsubsection{Model Soils}

Two different soils, i.e. in terms of the physico-chemical properties (agricultural type, $\mathrm{pH}$, content of the organic matrix), were collected from the arable layer in the 


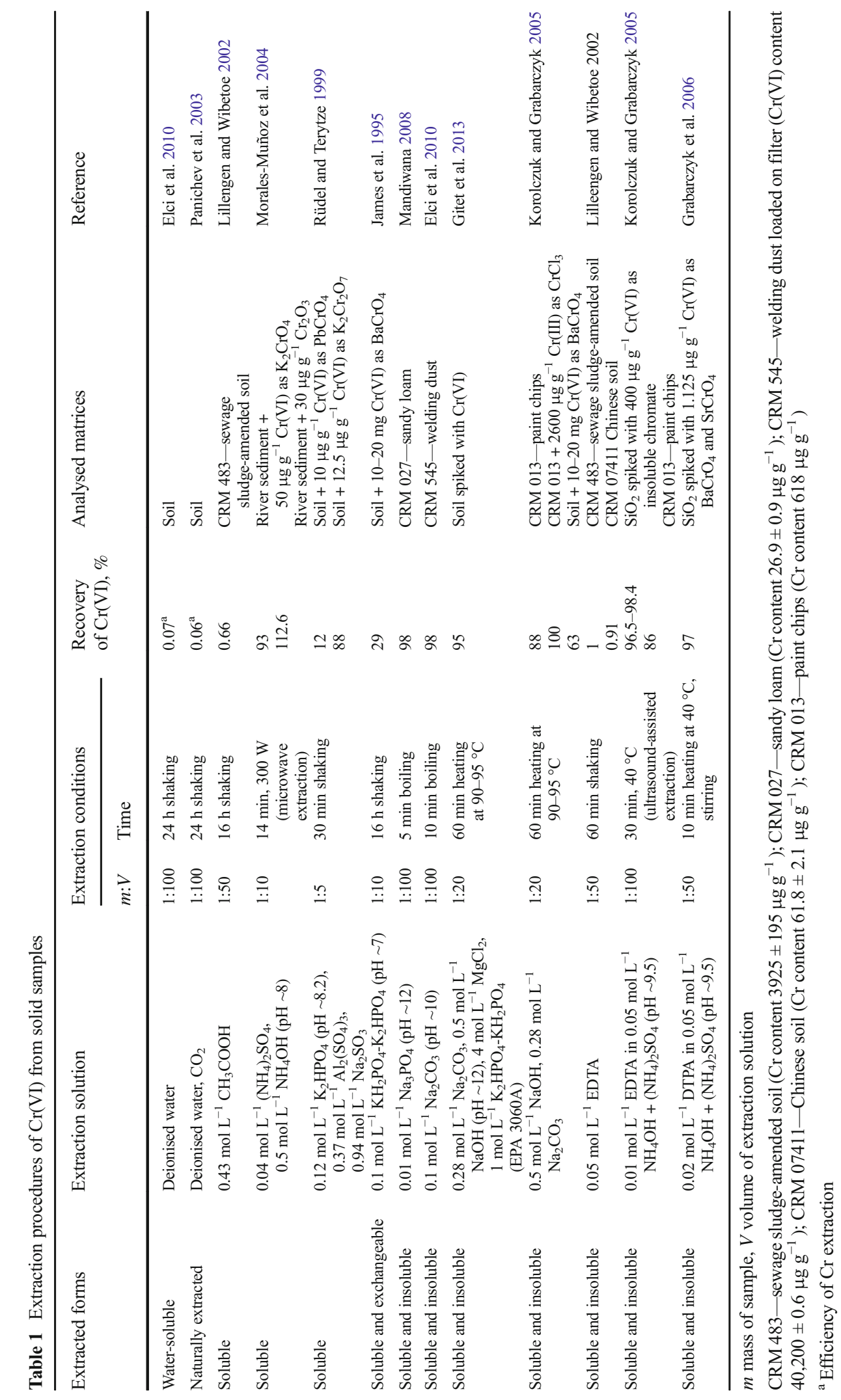


Podlasie Province (Poland). The soil was air-dried, homogenised and sieved using a 1-mm sieve. Both the content of organic carbon and the $\mathrm{pH}$ of the soils (in $\mathrm{KCl})$ were determined by using standard methods. The mineral soil $(\mathrm{M})$ contained $1.6 \%$ organic carbon $\left(\mathrm{pH}_{\mathrm{KCl}}=5.4\right)$, while the organic soil $(\mathrm{O})$ contained $10.5 \%$ organic carbon $\left(\mathrm{pH}_{\mathrm{KCl}}=6.1\right)$. The samples were spiked with different chromium compounds and used for optimisation of the extraction procedure.

\subsubsection{Spiking Procedures}

Three portions of each soil $(5 \mathrm{~g})$ were spiked with $50 \mathrm{mg} \mathrm{g}^{-1}$ of $\mathrm{Cr}(\mathrm{III})$ or $\mathrm{Cr}(\mathrm{VI})$ in a solid form $\left(\mathrm{CrCl}_{3} \cdot 6 \mathrm{H}_{2} \mathrm{O}, \mathrm{K}_{2} \mathrm{Cr}_{2} \mathrm{O}_{7}, \mathrm{BaCrO}_{4}\right)$. The samples were homogenised for $1 \mathrm{~h}$ in a ball mill. Next, $0.25 \mathrm{~g}$ of spiked soil was mixed with $4.75 \mathrm{~g}$ of natural soil and the sample was homogenised again for $1 \mathrm{~h}$. One gramme of each soil was mixed with $49 \mathrm{~g}$ of natural soil for $16 \mathrm{~h}$. In effect, each portion of soil $(50 \mathrm{~g})$ was spiked with $50 \mu \mathrm{g} \mathrm{g}^{-1}$ of chromium as $\mathrm{CrCl}_{3} 6 \mathrm{H}_{2} \mathrm{O}(\mathrm{O}-\mathrm{Cr}(\mathrm{III}) \mathrm{s}$, M$\mathrm{Cr}(\mathrm{III}) \mathrm{s}), \mathrm{K}_{2} \mathrm{Cr}_{2} \mathrm{O}_{7}(\mathrm{O}-\mathrm{Cr}(\mathrm{VI}) \mathrm{s}, \mathrm{M}-\mathrm{Cr}(\mathrm{VI}) \mathrm{s})$ and $\mathrm{BaCrO}_{4}$ (O-Cr(VI)s*, M-Cr(VI)s*). Two other portions of soil $(50 \mathrm{~g})$ were shaken with $50 \mathrm{~mL}$ of $50 \mu \mathrm{g} \mathrm{mL}^{-1}$ solution of $\mathrm{Cr}$ (III) or $\mathrm{Cr}(\mathrm{VI})$ compounds, such as $\mathrm{CrCl}_{3} 6 \mathrm{H}_{2} \mathrm{O}$ $\left(\mathrm{O}-\mathrm{Cr}(\mathrm{III})_{\text {liq }}, \mathrm{M}-\mathrm{Cr}(\mathrm{III})_{\text {liq }}\right.$ ) and $\mathrm{K}_{2} \mathrm{Cr}_{2} \mathrm{O}_{7}\left(\mathrm{O}-\mathrm{Cr}(\mathrm{VI})_{\text {liq }}\right.$, $\left.\mathrm{M}-\mathrm{Cr}(\mathrm{VI})_{\text {liq }}\right)$ ), for $2 \mathrm{~h}$ and dried in air. These samples were then used for further studies.

\subsubsection{Determination of the Total Content of $\mathrm{Cr}$}

The content of total chromium in both the natural and spiked soils was determined after wet mineralisation of soil in a mixture of $\mathrm{HNO}_{3}: \mathrm{HF}$ $(5 \mathrm{~mL}: 1 \mathrm{~mL})$. Samples $(0.2 \mathrm{~g})$ were heated in closed Teflon vessels in a microwave digestion system (Ethos Plus, Milestone, Italy) according to optimised microwave program: $250 \mathrm{~W}$ for $2.5 \mathrm{~min}$, $500 \mathrm{~W}$ for $5 \mathrm{~min}$ and $700 \mathrm{~W}$ for $15 \mathrm{~min}$. The process was repeated twice for total digestion of soil. The obtained solutions were transferred into polyethylene vessels, diluted with Milli-Q water to the final volume of $15 \mathrm{~mL}$ and analysed by ETAAS. The chromium content in the mineral soil (M) was $16.9 \mu \mathrm{g} \mathrm{g}^{-1}$, while in the organic soil (O) it was $18.3 \mu \mathrm{g} \mathrm{g}^{-1}$. The average content of chromium in mineral soil spiked with different chromium compounds was $34.2 \pm 5.1 \mu \mathrm{g} \mathrm{g}^{-1}$ (the average spiking efficiency was equal to $68 \%$ ), while in the spiked organic soil it was $38.4 \pm 4.5 \mu \mathrm{g} \mathrm{g}^{-1}$ (the average spiking efficiency was equal to $76 \%$ ).

\subsubsection{Soil Samples}

The soils examined in this work were collected from industrially contaminated area of a closed down leather tannery in Krynki (Podlasie Province, Poland). The content of $\mathrm{Cr}(\mathrm{VI})$ in soil was evaluated by using the developed procedure.

\subsubsection{CRM}

Certified reference material of sandy clay soil CRM 041 (Sigma-Aldrich, Germany) with certified $\mathrm{Cr}(\mathrm{VI})$ content $\left(86.3 \pm 2.96 \mu \mathrm{g} \mathrm{g}^{-1}\right)$ was used for the accuracy studies.

\subsubsection{Extraction Procedures}

The extraction procedures used to evaluate the efficiency of chromium released from the soils are summarised in Table 2. Uniform extraction conditions were always used. A total of $50 \mathrm{~mL}$ of one of the extraction solutions was added to each soil sample (mass of $1 \mathrm{~g}$ ). The suspensions were rotated for $16 \mathrm{~h}$ at room temperature $\left(22 \pm 2{ }^{\circ} \mathrm{C}\right)$ and next centrifuged at $3000 \mathrm{rpm}$ for $15 \mathrm{~min}$. The tubes for the hot carbonate extraction, after the addition of extraction solution, were placed on a preheated hot plate and maintained at $90-95{ }^{\circ} \mathrm{C}$ for $10 \mathrm{~min}$. The supernatants, after centrifugation and appropriate dilution (5-100 times), were used to determine the chromium concentration by ETAAS. All analyses were carried out in triplicates. Recovery of spiked chromium obtained in various extraction procedures was assessed as follows:

$R(\%)=\left(m_{\mathrm{exsp}}-m_{\mathrm{exnat}}\right) / m_{\mathrm{sp}} \times 100 \%$

where $m_{\text {exsp }}$ - mass of $\mathrm{Cr}$ extracted from spiked soil

$m_{\text {exnat }}$ - mass of $\mathrm{Cr}$ extracted from soil

$m_{\mathrm{sp}}$ - mass of spiked $\mathrm{Cr}$

The mass of chromium extracted from soil was calculated on the basis of an external calibration graph prepared for the given extracting solution. 
Table 2 The efficiency of Cr extraction from natural soil and the recovery of $\mathrm{Cr}(\mathrm{III})$ and $\mathrm{Cr}(\mathrm{VI})$ from spiked soil by using various extraction solutions (mass of soil $1 \mathrm{~g}$, volume of extraction solution $50 \mathrm{~mL}$, extraction for $16 \mathrm{~h}$ at room temperature)

\begin{tabular}{|c|c|c|c|c|}
\hline \multirow[t]{2}{*}{ Extraction solution } & \multirow[t]{2}{*}{ Type of soil } & \multirow{2}{*}{$\begin{array}{l}\text { Efficiency of } \mathrm{Cr} \\
\text { extraction, } \% \\
\text { Natural soil }\end{array}$} & \multicolumn{2}{|c|}{ Recovery of Cr, \% } \\
\hline & & & $\begin{array}{l}\text { Soil spiked } \\
\text { with } \mathrm{Cr}(\mathrm{III})\end{array}$ & $\begin{array}{l}\text { Soil spiked } \\
\text { with } \mathrm{Cr}(\mathrm{VI})\end{array}$ \\
\hline \multirow[t]{2}{*}{$0.43 \mathrm{~mol} \mathrm{~L}^{-1} \mathrm{CH}_{3} \mathrm{COOH}(\mathrm{pH} \sim 2.7)$} & Organic & 0.28 & $1.9-13.1$ & $14.6-23.2$ \\
\hline & Mineral & 0.25 & $1.7-16.0$ & $14.9-29.2$ \\
\hline \multirow{2}{*}{$\begin{array}{l}0.1 \mathrm{~mol} \mathrm{~L}^{-1} \mathrm{~K}_{2} \mathrm{HPO}_{4} \text { with addition of } \\
1 \mathrm{~mL} 0.37 \mathrm{~mol} \mathrm{~L}^{-1} \mathrm{Al}_{2}\left(\mathrm{SO}_{4}\right)_{3}+1 \mathrm{~mL} \\
0.94 \mathrm{~mol} \mathrm{~L}^{-1} \mathrm{Na}_{2} \mathrm{SO}_{3}(\mathrm{pH} \sim 8.0 \\
\left.1.56 \mathrm{~mol} \mathrm{~L}^{-1} \mathrm{H}_{3} \mathrm{PO}_{4}\right)\end{array}$} & Organic & 1.0 & $0.7-7.4$ & $4.6-14.1$ \\
\hline & Mineral & 0.4 & $0.9-1.4$ & $5.5-12.1$ \\
\hline \multirow[t]{2}{*}{$0.01 \mathrm{~mol} \mathrm{~L}^{-1} \mathrm{Na}_{3} \mathrm{PO}_{4}(\mathrm{pH} \sim 11.0)$} & Organic & 4.7 & $1.4-15.8$ & $16.6-80.1$ \\
\hline & Mineral & 4.3 & $2.1-17.0$ & $34.7-77.9$ \\
\hline \multirow[t]{2}{*}{$0.1 \mathrm{~mol} \mathrm{~L}^{-1} \mathrm{Na}_{2} \mathrm{CO}_{3}(\mathrm{pH} \sim 10.0)$} & Organic & 10.7 & $2.0-35.6$ & $35.6-109.8$ \\
\hline & Mineral & 1.7 & $1.5-8.1$ & $34.7-111.5$ \\
\hline \multirow{2}{*}{${ }^{\mathrm{a}} 0.1 \mathrm{~mol} \mathrm{~L}^{-1} \mathrm{Na}_{2} \mathrm{CO}_{3}(\mathrm{pH} \sim 10.0)$} & Organic & 14.2 & $5.3-73$ & $68.7-98.2$ \\
\hline & Mineral & 6.0 & $3.5-22.9$ & $43.2-99.8$ \\
\hline \multirow{2}{*}{$\begin{array}{l}0.01 \mathrm{~mol} \mathrm{~L}^{-1} \text { EDTA }(\mathrm{pH} \sim 9.5 \\
\left.\quad 0.05 \mathrm{~mol} \mathrm{~L}^{-1}\left(\mathrm{NH}_{4}\right)_{2} \mathrm{SO}_{4}+25 \% \mathrm{NH}_{4} \mathrm{OH}\right)\end{array}$} & Organic & 7.7 & $3.2-37.5$ & $42.9-106.4$ \\
\hline & Mineral & 3.3 & $2.0-17.2$ & $53.9-110.7$ \\
\hline \multirow{2}{*}{$\begin{array}{l}0.02 \mathrm{~mol} \mathrm{~L}^{-1} \text { DTPA }\left(\mathrm{pH} \sim 9.5 ; 0.05 \mathrm{~mol} \mathrm{~L}^{-1}\right. \\
\left.\quad\left(\mathrm{NH}_{4}\right)_{2} \mathrm{SO}_{4}+25 \% \mathrm{NH}_{4} \mathrm{OH}\right)\end{array}$} & Organic & 12.8 & $3.8-48.3$ & $34.0-98.9$ \\
\hline & Mineral & 3.5 & $10.5-50.4$ & $51.2-103.4$ \\
\hline
\end{tabular}

${ }^{\mathrm{a}}$ extraction by heating of suspension at $90-95^{\circ} \mathrm{C}$ for $10 \mathrm{~min}$

\section{Results and Discussion}

\subsection{An Appraisal of Extraction Procedures of Chromium Species from Soil}

The selectivity of procedures originally proposed for leaching of chromium(VI) species from solid samples (listed in Table 1) was tested. The mass of chromium extracted from mineral and organic soil spiked with different trivalent and hexavalent compounds of chromium (as $\mathrm{CrCl}_{3} \cdot 6 \mathrm{H}_{2} \mathrm{O}, \mathrm{K}_{2} \mathrm{CrO}_{4}, \mathrm{BaCrO}_{4}$ ) was determined, and recoveries were calculated (Table 2). The obtained results are shown in Fig. 1. For a comparison, all procedures were also applied for extraction of native chromium from unpolluted soils. The efficiency of chromium extraction was higher from organic soil $(0.3-13 \%$ of its total content) than from mineral soil ( 0.3 to $4.4 \%)$ (Fig. 1c).

Acetic acid at various concentrations was recommended in order to determine the exchangeable and carbonate-bound chromium fraction in the soil (Lillengen and Wibetoe 2002; KrasnodębskaOstrega et al. 2009). The amount of native chromium extracted from natural soil with $0.43 \mathrm{~mol} \mathrm{~L}^{-1}$ solution of $\mathrm{CH}_{3} \mathrm{COOH}$ was very low $(<0.3 \%)$. The recovery of chromium from soils spiked with $\mathrm{Cr}(\mathrm{VI})$ forms was higher (14-29\%) than from soils spiked with $\mathrm{Cr}$ (III) forms (1.7-16\%). It was found that $\mathrm{Cr}$ (III) added to the soil in a liquid form was extracted in a higher amount (13-16\%) than that added in a solid form (1.7-1.9\%). The opposite correlation was observed for $\mathrm{Cr}(\mathrm{VI})$ (Fig. 1a, b).

Some papers mentioned that extraction of $\mathrm{Cr}(\mathrm{VI})$ in alkaline solution is preferable to acid extraction because it ensures better solubility of some of the chromate compounds (James et al. 1995). The extraction procedure using phosphate buffer is devoted to the leaching of soluble Cr(VI) forms (Rüdel and Terytze 1999). The addition of $\mathrm{Al}_{2}\left(\mathrm{SO}_{4}\right)_{3}$ enhances precipitation of $\mathrm{Cr}(\mathrm{III})$ in the sulphate form, while $\mathrm{Na}_{2} \mathrm{SO}_{3}$ prevents oxidation reactions. The efficiency of chromium extraction from natural soil with $0.1 \mathrm{~mol} \mathrm{~L}^{-1}$ solution of $\mathrm{K}_{2} \mathrm{HPO}_{4}$ was slightly higher $(0.4-1 \%)$ than that with $\mathrm{CH}_{3} \mathrm{COOH}$. However, this procedure was less effective for the extraction of chromium(VI) from spiked soils as its recovery was in the range of 4.6-14.1\%; surprisingly, it was lower for the soluble (as $\mathrm{K}_{2} \mathrm{CrO}_{4}$ ) than for the insoluble (as $\mathrm{BaCrO}_{4}$ ) form of $\mathrm{Cr}(\mathrm{VI})$ (Fig. 1a, b). Such low recovery of insoluble $\mathrm{Cr}(\mathrm{VI})$ from the soil $(<12 \%)$ was also reported by others (Szulczewski et al. 1997). This 
a)

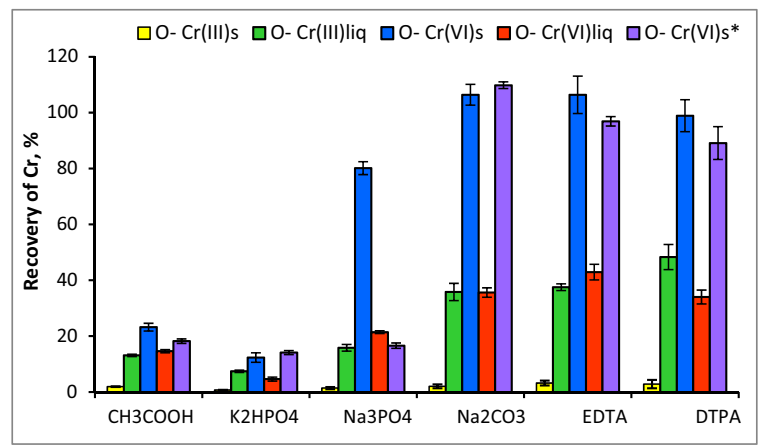

b)

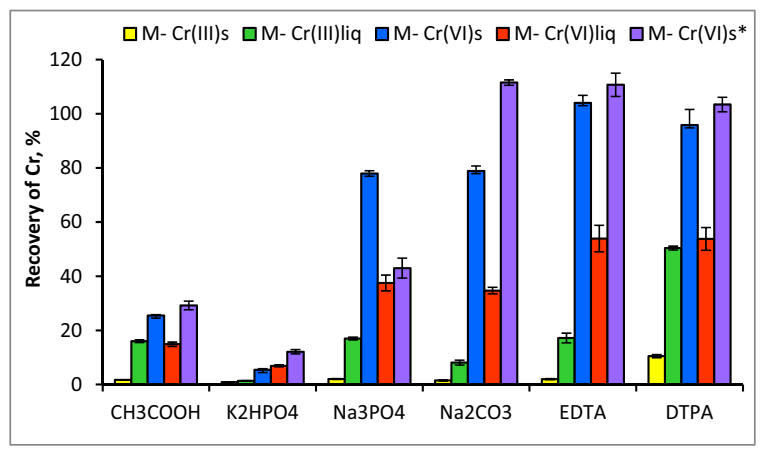

c)

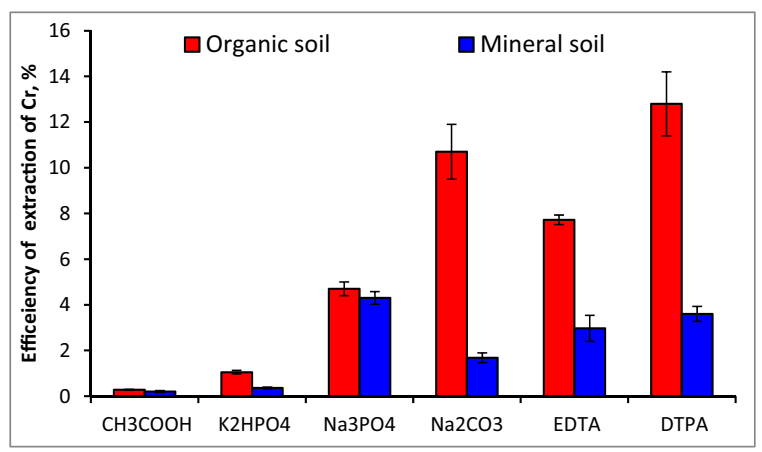

Fig. 1 The recovery of chromium from soil spiked with $\mathrm{Cr}(\mathrm{III})$ and $\mathrm{Cr}(\mathrm{VI})$ in solid (s) or liquid (liq) forms extracted with using various reagents. a Organic soil. b Mineral soil. c The efficiency of chromium extraction from native soil with using various reagents (value \pm standard deviation, $n=3$ )

procedure is then not recommended for the extraction of total $\mathrm{Cr}(\mathrm{VI})$, as was proposed in James et al. (1995). It is worth noting that up to $7.4 \%$ of spiked $\mathrm{Cr}$ (III) was also extracted with this reagent.

During extraction of soil with the $\mathrm{Na}_{3} \mathrm{PO}_{4}$ solution, insoluble $\mathrm{Cr}(\mathrm{VI})$ compounds (e.g. $\mathrm{BaCrO}_{4}$ ) are transformed into soluble forms (e.g. $\mathrm{Na}_{2} \mathrm{CrO}_{4}$ ) (Mandiwana 2008). The procedure should remove all common metals, e.g. insoluble phosphates, oxides or hydroxides, so the solution should contain only $\mathrm{CrO}_{4}{ }^{2-}$ ions. The efficiency of chromium extraction from natural soil with $0.01 \mathrm{~mol} \mathrm{~L}^{-1} \mathrm{Na}_{3} \mathrm{PO}_{4}$ was below $5 \%$. Higher recovery of chromium was obtained from soil spiked with solid $\mathrm{K}_{2} \mathrm{CrO}_{4}(80 \%)$ than from soil spiked with $\mathrm{BaCrO}_{4}(20$ $40 \%$ ). Recovery of $\mathrm{Cr}(\mathrm{III})$ forms was similar to that obtained with $\mathrm{CH}_{3} \mathrm{COOH}$, namely $2 \%$ from soil spiked with solid $\mathrm{CrCl}_{3}$ and $17 \%$ from soil spiked with $\mathrm{CrCl}_{3}$ solution (Fig. 1a, b).

Leaching of soil with $0.1 \mathrm{~mol} \mathrm{~L}^{-1} \mathrm{Na}_{2} \mathrm{CO}_{3}$ in alkaline solution was proposed for extraction of soluble and insoluble Cr(VI) forms (Vitale et al. 1994). Such treatment of samples transformed insoluble $\mathrm{Cr}(\mathrm{VI})$ salts into soluble chromate ions, whereas all common metals, including $\mathrm{Cr}(\mathrm{III})$, were removed as insoluble carbonates, oxides or hydroxycarbonates. The efficiency of extraction of native $\mathrm{Cr}$ with this reagent was $2 \%$ from mineral and $11 \%$ from organic soil. The recovery of chromium added as a solid $\mathrm{Cr}$ (III) salt was about $2 \%$ from both types of soil, while added as a solution, it increased to 8 and 35\% from mineral and organic soil, respectively. High recovery of chromium (80-110\%) from both types of soil spiked with soluble and insoluble solid $\mathrm{Cr}(\mathrm{VI})$ salts was observed. Lower recovery of chromium added as a solution of $\mathrm{CrO}_{4}{ }^{2-}$ suggests that $\mathrm{Cr}(\mathrm{VI})$ was partly reduced by the sample matrix to insoluble $\mathrm{Cr}$ (III), which supports the observations of Vitale et al. (1997) that soluble $\mathrm{CrO}_{4}{ }^{2-}$ is reduced to insoluble $\mathrm{Cr}_{2} \mathrm{O}_{3}$. This effect was also observed in all other procedures (Fig. 1a, b). In order to shorten the procedure, the extraction of soil with $\mathrm{Na}_{2} \mathrm{CO}_{3}$ solution at a high temperature, i.e. $90-95^{\circ} \mathrm{C}$, for $10 \mathrm{~min}$ (Panichev et al. 2003) was tested for $\mathrm{Cr}(\mathrm{VI})$ leaching. It was observed that the colour of the alkaline extract was much darker, indicating that at higher temperature, the organic components of soil, e.g. humic acids, were better solubilised. This effect was more visible for organic soil. A small increase was observed in the extraction efficiency of native chromium $(\sim 4 \%)$ and the recovery of solid $\mathrm{Cr}(\mathrm{III})$ spike $(\sim 2 \%)$ from organic and mineral soil. The recovery of $\mathrm{Cr}(\mathrm{VI})$ spikes added as a solid in soluble and insoluble forms from both types of soil was quantitative, which indicates that the presence of liberated organic compounds in the extract did not significantly influence the reduction process of $\mathrm{Cr}(\mathrm{VI})$ species (Vitale et al. 1997). The highest increase in the recovery of analytes $(\sim 35 \%)$ in comparison to unheated treatment was observed for organic soil spiked with solutions of $\mathrm{Cr}$ (III) and soluble $\mathrm{Cr}$ (VI) (Fig. 2). The increase in recoveries 
Fig. 2 The recovery of chromium from soil spiked with $\mathrm{Cr}$ (III) and $\mathrm{Cr}$ (VI) in solid (s) or liquid (liq) forms extracted with $\mathrm{Na}_{2} \mathrm{CO}_{3}$ solution at room temperature or heated to $90-95^{\circ} \mathrm{C}$ (value \pm standard deviation, $n=3$ )

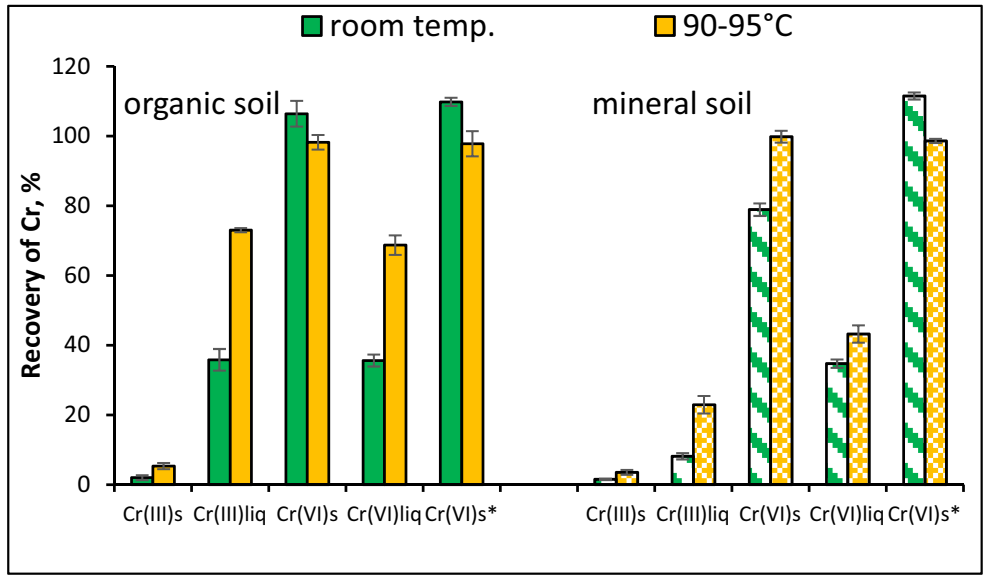

of analytes from mineral soil spiked with the same chromium forms was slightly lower, i.e. $15 \%$ for $\mathrm{Cr}(\mathrm{III})$ and $8 \%$ for soluble $\mathrm{Cr}(\mathrm{VI})$. The observed changes suggest that immobile chromium species were converted into mobile forms. Most probably under alkaline conditions, high temperature and the presence of carbonate and organic matter, $\mathrm{Cr}$ (III) was oxidised to $\mathrm{Cr}(\mathrm{VI})$, which was extracted more efficiently. Extraction in high temperature resulted in the release of chromium species adsorbed on soil particles due to the dissolution of the organic and inorganic substances present in the soil. The studies showed only a small increase in the extraction efficiency of chromium from native soil (by 4\%) at an elevated temperature. This suggests that native chromium is present in a form that is more resistant to oxidation and solubilisation.

Extraction of chromium with EDTA and DTPA solutions is based on the transformation of insoluble $\mathrm{Cr}(\mathrm{VI})$ compounds into soluble species by complexation of the metal ions that form insoluble chromates (Korolczuk and Grabarczyk 2005; Grabarczyk et al. 2006). The extraction of chromium with EDTA and DTPA was similar to that obtained with the $\mathrm{Na}_{2} \mathrm{CO}_{3}$ solution. The efficiency of extraction of chromium from natural soil was in the range of $3.3-12.8 \%$. Chromium(VI) added in a solid form was quantitatively recovered from both soils. The recoveries of $\mathrm{Cr}$ (III) and $\mathrm{Cr}(\mathrm{VI})$ spiked as a liquid were in the range of $17-54 \%$. A higher percentage of metal was extracted with EDTA than with DTPA from soil spiked with the $\mathrm{Cr}(\mathrm{VI})$ form. The results showed that EDTA and DTPA were the most efficient extractants of $\mathrm{Cr}(\mathrm{VI})$ among all the tested reagents; however, they also leached significant amounts of $\mathrm{Cr}$ (III) (Fig. 1a, b).
On the basis of the performed experiments, the tested reagents were sorted according to their extraction potential into $\mathrm{Cr}(\mathrm{III})$ and $\mathrm{Cr}(\mathrm{VI})$ species. For the $\mathrm{Cr}$ (III) species, the differences in the extraction power of the reagents used were observed depending on the phase of the introduced spike. For $\mathrm{Cr}$ (III) added as a solid to mineral and organic soil, the order of extraction reagents was as follows: $\mathrm{K}_{2} \mathrm{HPO}_{4}(\sim 1 \%)<\mathrm{CH}_{3} \mathrm{COOH}, \mathrm{Na}_{3} \mathrm{PO}_{4}$, $\mathrm{Na}_{2} \mathrm{CO}_{3}(\sim 2 \%) \leq$ EDTA $(2-3.2 \%)<$ DTPA $(3.8-10 \%)$. When $\mathrm{Cr}$ (III) was introduced as a liquid, a different extraction order of reagents was observed for the two tested types of soil. The spike of Cr(III) from mineral soil was extracted with increasing efficiency by using the following reagents: $\mathrm{K}_{2} \mathrm{HPO}_{4}(1.4 \%)<\mathrm{Na}_{2} \mathrm{CO}_{3}$ $(8 \%)<\mathrm{CH}_{3} \mathrm{COOH}, \mathrm{Na}_{3} \mathrm{PO}_{4}$, EDTA $(\sim 17 \%)<$ DTPA $(50 \%)$, whereas from organic soil the order was as follows: $\mathrm{K}_{2} \mathrm{HPO}_{4}(7 \%)<\mathrm{CH}_{3} \mathrm{COOH}, \mathrm{Na}_{3} \mathrm{PO}_{4}$ $(\sim 15 \%)<\mathrm{Na}_{2} \mathrm{CO}_{3}$, EDTA $(\sim 36 \%)<$ DTPA $(48 \%)$. For organic soil, the extraction of $\mathrm{Cr}$ (III) with hot $\mathrm{Na}_{2} \mathrm{CO}_{3}$ was the most efficient procedure (recovery: $5.3 \%$ for solid spike and $73 \%$ for liquid spike). For mineral soil, this procedure had a higher extraction power than $\mathrm{CH}_{3} \mathrm{COOH}, \mathrm{Na}_{3} \mathrm{PO}_{4}$ and EDTA, but still lower than DTPA (recovery: $3.5 \%$ for solid spike and $22 \%$ for liquid spike). It should be noted that none of the tested procedures allowed for total recovery of $\mathrm{Cr}$ (III), which indicates a strong interaction of the spike with the matrix of the soil. The highest recovery of $\mathrm{Cr}$ (III) from both types of soil was obtained with DTPA solution $(\sim 50 \%)$.

Spikes of $\mathrm{Cr}(\mathrm{VI})$ introduced into the organic soil in either a liquid or solid phase were extracted with increasing efficiency by using the following reagents: $\mathrm{K}_{2} \mathrm{HPO}_{4}$ $(5-14 \%)<\mathrm{CH}_{3} \mathrm{COOH}(15-23 \%)<\mathrm{Na}_{3} \mathrm{PO}_{4}(17-$ 
$80 \%)<$ DTPA, $\mathrm{Na}_{2} \mathrm{CO}_{3}$, EDTA (35-110\%). The order of reagents for mineral soil spiked with insoluble $\mathrm{Cr}(\mathrm{VI})$ was the same as for organic soil. In the case of mineral soil spiked with soluble $\mathrm{Cr}(\mathrm{VI})$ (as a liquid and solid form), similar power of $\mathrm{Na}_{3} \mathrm{PO}_{4}$ and $\mathrm{Na}_{2} \mathrm{CO}_{3}$ towards $\mathrm{Cr}(\mathrm{VI})$ was observed; therefore, the order of the reagents was slightly different: $\mathrm{K}_{2} \mathrm{HPO}_{4}(5-7 \%)<\mathrm{CH}_{3} \mathrm{COOH}$ $(15-25 \%)<\mathrm{Na}_{3} \mathrm{PO}_{4}=\mathrm{Na}_{2} \mathrm{CO}_{3}(35-78 \%)<\mathrm{DTPA}$, EDTA (51-105\%). The total recovery of solid $\mathrm{Cr}(\mathrm{VI})$ spikes from organic soil was obtained using $\mathrm{Na}_{2} \mathrm{CO}_{3}$, DTPA and EDTA solutions, whereas from mineral soil it was obtained with DTPA and EDTA solutions. The most efficient extraction of $\mathrm{Cr}(\mathrm{VI})$ from both samples was obtained with hot $\mathrm{Na}_{2} \mathrm{CO}_{3}$, thus allowing for quantitative recovery of the solid $\mathrm{Cr}(\mathrm{VI})$ spike.

The order of the tested reagents towards extraction of native chromium from organic soil was the same as for the spike of $\mathrm{Cr}(\mathrm{VI})$ and was as follows: $\mathrm{CH}_{3} \mathrm{COOH}$ $(0.3 \%)<\mathrm{K}_{2} \mathrm{HPO}_{4}(1 \%)<\mathrm{Na}_{3} \mathrm{PO}_{4}(4.7 \%)<$ EDTA $(7.7 \%)<\mathrm{Na}_{2} \mathrm{CO}_{3}(11 \%)<$ DTPA $(12.8 \%)<\mathrm{Na}_{2} \mathrm{CO}_{3}$ hot $(14.2 \%)$. For mineral soil, higher extraction power towards native chromium was demonstrated by the $\mathrm{Na}_{3} \mathrm{PO}_{4}$ solution and hot $\mathrm{Na}_{2} \mathrm{CO}_{3}$; therefore, the order of extraction reagents was as follows: $\mathrm{K}_{2} \mathrm{HPO}_{4}$, $\mathrm{CH}_{3} \mathrm{COOH}(0.3 \%)<\mathrm{Na}_{2} \mathrm{CO}_{3}(1.6 \%)<$ EDTA, DTPA $(3.5 \%)<\mathrm{Na}_{3} \mathrm{PO}_{4}(4.4 \%)<\mathrm{Na}_{2} \mathrm{CO}_{3}$ hot $(6 \%)$.

It was found that the $\mathrm{CH}_{3} \mathrm{COOH}$ and $\mathrm{K}_{2} \mathrm{HPO}_{4}$ solutions exhibited the lowest extraction power towards all spikes of chromium, which is consistent with the literature data suggesting that these reagents be used for extraction of soluble $\mathrm{Cr}(\mathrm{VI})$ forms (Lillengen and Wibetoe 2002; Rüdel and Terytze 1999). Lower recovery of $\mathrm{Cr}(\mathrm{VI})$ spiked as a soluble chromate was obtained with $\mathrm{K}_{2} \mathrm{HPO}_{4}$ than was reported in Rüdel and Terytze (1999) ( 12 versus $88 \%$ ), whereas a similar recovery was obtained for insoluble chromates $(\sim 12 \%)$. Among the other reagents proposed for extraction of soluble and insoluble $\mathrm{Cr}(\mathrm{VI})$ forms, only $\mathrm{Na}_{3} \mathrm{PO}_{4}$ was ineffective, even when applied by others (Mandiwana 2008). The results obtained in our experiments in procedures using $\mathrm{Na}_{2} \mathrm{CO}_{3}$, EDTA and DTPA solutions were comparable to the results presented in the literature for samples spiked with $\mathrm{Cr}(\mathrm{VI})$ in the form of soluble and insoluble chromate (see Table 1) (Korolczuk and Grabarczyk 2005; Grabarczyk et al. 2006; Lillengen and Wibetoe 2002). The efficiency of extraction of native chromium with $\mathrm{CH}_{3} \mathrm{COOH}$ and EDTA as obtained in our work was the same as that reported by Lillengen and Wibetoe (2002) for CRM 483 sewage sludgeamended soil and CRM 07411 Chinese soil.

The choice of procedure for selective extraction of $\mathrm{Cr}(\mathrm{VI})$ using $0.1 \mathrm{~mol} \mathrm{~L}^{-1} \mathrm{Na}_{2} \mathrm{CO}_{3}$ at room temperature is highly recommended for mineral soil samples, as it provided quantitative recovery of $\mathrm{Cr}(\mathrm{VI})$ and slight extraction of $\mathrm{Cr}(\mathrm{III})(8 \%)$. This procedure may also be appropriate for natural organic soil, despite the higher recovery of $\mathrm{Cr}(\mathrm{III})$, which was probably the effect of better solubility of the spiked form of chromium $\left(\mathrm{CrCl}_{3}\right)$. Taking into account the efficiency of extraction of native chromium from both mineral and organic soil, in which $\mathrm{Cr}$ (III) forms predominate, and the advantage of shortening the extraction time, the extraction procedure using $\mathrm{Na}_{2} \mathrm{CO}_{3}$ at high temperature may also be recommended for mineral soil.

As was discussed above, releasing chromium from native (model soils) and anthropogenic contaminated soil (spiked soils) was different. Therefore, the characteristics of the environmental samples and the sources of their contamination should be known to properly select the extraction procedure.

\subsection{An Impact of Physical Form of Waste on Chromium} Mobility in Soil

The studies performed here show that the differences in the recovery of spiked chromium forms depend not only on the chromium oxidation state and type of soil but also on the physical phase of the spike. Cr(III) forms, considered to be immobile and insoluble, were partly extracted from the soil, though less efficiently when $\mathrm{Cr}$ (III) was spiked in a solid form than in a liquid form. The recovery of $\mathrm{Cr}$ (III) added as a solid compound was only $4 \%$ from the organic soil and $2 \%$ from the mineral soil, irrespective of the extraction procedure that was used (Fig. 1a, b). Higher recovery of chromium with the DTPA solution (up to $10 \%$ ) was observed, which might be an effect of the weak dissolution of the solid spike due to a shift in the chemical equilibrium towards complexation of $\mathrm{Cr}$ (III) ions with the chelating reagent. Such an effect was not observed for extraction with EDTA due to the slow rate of the formation of $\mathrm{Cr}$ (III)-EDTA complexes. Cr(III) added to the soil in the form of a solution was extracted to a higher extent. Its recovery from mineral soil reached $17 \%$, while from organic soil it was $37 \%$. Also in this case, the recovery of chromium with DTPA solution from both types of soil was highest 
(up to $\sim 50 \%$ ). Low recoveries of added $\mathrm{Cr}$ (III) ions suggest the occurrence of a strong interaction between the spike and the soil. Probably, $\mathrm{Cr}$ (III) cations, added as a spike, are immobilised/sorbed on the negatively charged surface of particles of the soil components. The precipitation of $\mathrm{Cr}(\mathrm{OH})_{3}$, which gradually undergoes dehydration and crystallisation as $\mathrm{Cr}_{2} \mathrm{O}_{3}$, is also possible. Higher recoveries of $\mathrm{Cr}$ (III) (35-48\%) obtained from the organic soil by $\mathrm{Na}_{2} \mathrm{CO}_{3}$, EDTA and DTPA solutions suggest that some soluble organic complexes of $\mathrm{Cr}$ (III) with fulvic/humic or citric acid could also be formed in the presence of humic substances.

Since the phenomenon of inter-conversion of chromium oxidation forms under environmental conditions has already been reported (Kotaś and Stasicka 2000; Metze et al. 2005; Dhal et al. 2013), oxidation of the added $\mathrm{Cr}(\mathrm{III})$ to $\mathrm{Cr}(\mathrm{VI})$ in the tested soil could not be excluded. Such oxidation may arise only under certain circumstances in the presence of $\mathrm{MnO}_{2}$ or molecular oxygen (Apte et al. 2005; Pantsar-Kallio and Oksanen 2001). Dhal et al. (2013), in their review, stated that oxygen does not react appreciably with $\mathrm{Cr}$ (III), while oxidation of $\mathrm{Cr}$ (III) by $\mathrm{MnO}_{2}$ depends on the concentration of water-soluble chromium, $\mathrm{pH}$ of soil, amount of organic matter and drainage of the soil. For the studied samples, the presence of $\mathrm{Cr}$ (III) in the aqueous phase of soil was limited due to its adsorption on the soil particles, the precipitation and formation of stable complexes with humic substances. Therefore, oxidation of the added spike of $\mathrm{Cr}$ (III) during extraction at room temperature was less probable. However, during heating of soil with $\mathrm{Na}_{2} \mathrm{CO}_{3}$ solution, the probable oxidation of $\mathrm{Cr}(\mathrm{III})$ to mobile $\mathrm{Cr}(\mathrm{VI})$ forms arose, as higher recovery of $\mathrm{Cr}$ spikes was observed. The alkaline conditions, high temperature and presence of organic matter led to oxidation of $\mathrm{Cr}(\mathrm{III})$ to the $\mathrm{Cr}(\mathrm{VI})$ form.

The recoveries of $\mathrm{Cr}(\mathrm{VI})$ forms, which are considered to be more mobile than $\mathrm{Cr}$ (III) forms, were also dependent on the physical state of $\mathrm{Cr}(\mathrm{VI})$ added to the soil. Generally, $\mathrm{Cr}(\mathrm{VI})$ added as a solution was less extractable than when added as a solid compound (soluble and insoluble salts). Probably, such a phenomenon was the effect of the reduction of $\mathrm{Cr}(\mathrm{VI})$ to $\mathrm{Cr}(\mathrm{III})$ by the matrix components of the soil. Although the reduction of $\mathrm{Cr}(\mathrm{VI})$ to $\mathrm{Cr}(\mathrm{III})$ by the soil organic compounds and the oxidation of $\mathrm{Cr}(\mathrm{III})$ to $\mathrm{Cr}(\mathrm{VI})$ by the manganese oxides result from thermodynamically spontaneous reactions (James 2001), the reduction process arises more easily than oxidation under environmental conditions
(Dhal et al. 2013; Brose and James 2010). The concentration of the reducing agents such as organic matter, sulphides or Fe(II)-bearing minerals in the soil and the soil $\mathrm{pH}$ affect the redox behaviour of chromium (Apte et al. 2005; Metze et al. 2005). The rate of reduction of $\mathrm{Cr}(\mathrm{VI})$ by the humic acids increases along with the decrease in $\mathrm{pH}$ (Dhal et al. 2013). The content of organic matter $(18.1 \%)$ and acidic conditions in organic soil $(\mathrm{pH}$ 6.1) facilitated the reduction of the added $\mathrm{Cr}(\mathrm{VI})$ to $\mathrm{Cr}(\mathrm{III})$ to a large extent. In aerobic soil, which contains appropriate organic substances for the redox process, the reduction of $\mathrm{Cr}(\mathrm{VI})$ in a slightly alkaline environment is also possible. The formed $\mathrm{Cr}$ (III) species were probably immobilised on the soil particles. Therefore, in all of the tested extraction solutions, the recovery of $\mathrm{Cr}(\mathrm{VI})$ added as a solution to the organic soil was almost the same as the recovery of the liquid spike of $\mathrm{Cr}$ (III). For the mineral soil, the acidic conditions enhanced the rate of release of the $\mathrm{Fe}$ (II) species from the minerals, which could then react with $\mathrm{Cr}(\mathrm{VI})$ in the aqueous phase. However, higher recovery of $\mathrm{Cr}(\mathrm{VI})$ than $\mathrm{Cr}$ (III) (both added in the liquid form) indicates that a smaller amount of $\mathrm{Cr}(\mathrm{VI})$ was converted into $\mathrm{Cr}(\mathrm{III})$ in the mineral soil.

The obtained results demonstrate the transformation of added chromium forms in the soil, which leads to a significant change in their initial mobility and finally in the recovery of added forms of chromium. The most important conclusion from this experiment is that the mobility of chromium species depends not only on its oxidation state but also on its physical form as introduced into the environment, which is of great significance when chromium waste is disposed of into the environment.

\subsection{Validation of Extraction Procedures of Cr(VI) from Soil}

Validation of the extraction procedures based on using $0.1 \mathrm{~mol} \mathrm{~L}^{-1} \mathrm{Na}_{2} \mathrm{CO}_{3}$ solution, shaking the suspension of the sample for $16 \mathrm{~h}$ at room temperature or heating the suspension of the sample at $90-95{ }^{\circ} \mathrm{C}$ for $10 \mathrm{~min}$ was performed in order to obtain reliable and accurate results of chromium species extracted from the soil samples. During method validation, the following parameters were estimated: linearity, limit of detection (LOD) and limit of quantification (LOQ), precision, trueness and uncertainty of measurements of $\mathrm{Cr}(\mathrm{VI})$ content in soil extracted with $\mathrm{Na}_{2} \mathrm{CO}_{3}$. 
In order to verify the linearity of the calibration graph, $\mathrm{Cr}(\mathrm{VI})$ standards in a concentration range of 1$50 \mathrm{ng} \mathrm{mL}{ }^{-1}$ were prepared in a 100 times diluted $\mathrm{Na}_{2} \mathrm{CO}_{3}$ extraction solution and their absorbance was measured by ETAAS. Then the calibration graph was constructed as $A=f\left(C_{\mathrm{Cr}(\mathrm{VI})}\right)$ and the correlation factor was used to verify their linearity. It was found that the correlation factor $(R)$ was higher than 0.995 for the calibration graph prepared from the standard solutions at a concentration range of $1-30 \mathrm{ng} \mathrm{mL}^{-1}$. The obtained equation of the calibration graph was $y=0.0173 x+$ $0.0195(R=0.9992)$. The extraction solution was used as a blank sample to calculate the limit of detection of $\mathrm{Cr}(\mathrm{VI})$. The value of the limit of detection (LOD) was calculated according to the following equation: $\mathrm{LOD}=3 \mathrm{SD}_{\text {blank }} / b$, where $b$ is the slope of the calibration graph. The limit of quantification (LOQ) was calculated as $\mathrm{LOQ}=6 \mathrm{SD}_{\text {blank }} / b$. The LOD obtained for the extraction solution was $0.35 \mathrm{ng} \mathrm{mL}^{-1}$, while the LOQ was $0.71 \mathrm{ng} \mathrm{mL}^{-1}$. The volume of the extraction solutions and the mass of the soil samples were used for the calculations in order to evaluate these parameters for the soil samples. The LOD for $\mathrm{Cr}(\mathrm{VI})$ in soil was $17.5 \mu \mathrm{g} \mathrm{kg}^{-1}$, while the LOQ for soil was $35.5 \mu \mathrm{g} \mathrm{kg}^{-1}$.

The precision of measurements (expressed as the relative standard deviation (RSD)) was evaluated by analysing the standard solutions of $\mathrm{Cr}$ at a concentration of $4 \mathrm{n} \mathrm{mL}^{-1}$ in extraction solution on the same day. The obtained value of RSD for measurements of six independent standards was $1.2 \%$, which means that the precision of the measurements was satisfactory. The repeatability of extraction of chromium from the soil samples was evaluated by analysing extracts obtained by using the extraction solution at room temperature and heated to $90-95{ }^{\circ} \mathrm{C}$. Repeatability was expressed as RSD for six independent extractions of the same sample. It was found that for both extraction procedures, the values of RSD were in the range of $1-10 \%$ for both analysed types of soil; however, slightly lower values were obtained for the mineral soil.

The trueness of extraction procedures of chromium was evaluated by analysing the certified reference material of soil CRM 041 (contaminated sandy clay soil) with a certified value of the $\mathrm{Cr}(\mathrm{VI})$ content determined by using the normalised EPA $3060 \mathrm{~A}$ procedure $(60 \mathrm{~min}$ of boiling the sample at $90{ }^{\circ} \mathrm{C}$ in a solution of $0.28 \mathrm{~mol} \mathrm{~L}^{-1} \mathrm{Na}_{2} \mathrm{CO}_{3}, 0.5 \mathrm{~mol} \mathrm{~L}^{-1} \mathrm{NaOH}, 4 \mathrm{~mol} \mathrm{~L}^{-1}$ $\mathrm{MgCl}_{2}$ in $1 \mathrm{~mol} \mathrm{~L}^{-1}$ of phosphoric buffer). Good agreement of the content of $\mathrm{Cr}(\mathrm{VI})$ determined in $0.1 \mathrm{~mol} \mathrm{~L}^{-1}$
$\mathrm{Na}_{2} \mathrm{CO}_{3}$ extract obtained at room temperature $\left(82.2 \pm 5.5 \mu \mathrm{g} \mathrm{g}^{-1}, n=3\right)$ and after heating $\left(86.6 \pm 1.6 \mu \mathrm{g} \mathrm{g}^{-1}, n=3\right)$ with the certified value $\left(86.3 \pm 2.96 \mu \mathrm{g} \mathrm{g}^{-1}\right)$ indicates good accuracy of the selected extraction procedures. The recovery of $\mathrm{Cr}(\mathrm{VI})$ in CRM 041 was $95.2 \pm 6.3$ and $100.4 \pm 1.8 \%$, respectively, which proved that the developed procedures may be applied for analysis of natural soil. We did not observed any influence of matrices of CRM 041 (as a mineral soil with 15 times lower content of manganese than the total content of chromium) on the recovery of $\mathrm{Cr}(\mathrm{VI})$ obtained after using extraction procedure at elevated temperature. It is worth noting that the developed procedures are simpler than normalised EPA 3060A in terms of the composition of the extraction medium (only $\mathrm{Na}_{2} \mathrm{CO}_{3}$ solution), conditions of extraction (room temperature) and time of extraction (10 $\mathrm{min}$ in the case of heating the suspension of the soil sample).

The uncertainty of measurements of $\mathrm{Cr}(\mathrm{VI})$ content in soil extracted with $\mathrm{Na}_{2} \mathrm{CO}_{3}$ solution by developed procedures were evaluated in accordance with the Guide to the Expression of Uncertainty in Measurement (2008), similarly to the scheme presented by Leśniewska et al. 2016. The modelling approach, based on a model equation, in which individual components of uncertainty that contribute to uncertainty of measurement are quantified, was used for estimation of combined standard uncertainty of measurements. The obtained expanded uncertainty $(U)$ of measurements of $\mathrm{Cr}(\mathrm{VI})$ content in soil extracted with $\mathrm{Na}_{2} \mathrm{CO}_{3}$ solution at room temperature $\left(82.2 \pm 8.0 \mathrm{\mu g} \mathrm{g}^{-1} ; U=9.7 \%, k=2\right)$ was slightly higher than for extraction procedure at elevated temperature $\left(86.6 \pm 5.5 \mu \mathrm{g} \mathrm{g}^{-1} ; U=6.3 \%\right.$, $k=2$ ) due to a higher value of standard uncertainty of $\mathrm{Cr}(\mathrm{VI})$ recovery from CRM 041.

\subsection{Analysis of Soil Samples}

Samples of soil (1-7) were collected from an industrially contaminated area of an old leather tannery where chromium(III) sulphate was used during the tanning process. The tannery had functioned there since the 1960 s to the late 1990s. Samples 1, 2 and 3 were collected near the entrance to the wet, tanning and finishing departments (at a distance of 2-4 $\mathrm{m}$ from the building), respectively. Sample 4 was collected from the opposite side of the tannery building, probably along the route of transport of leather between the abovementioned departments. Samples 5, 6 and 7 were 
collected at a distance of 1-2 m outside the tannery area. From all location, three mixed sub-samples were collected from a surface layer at a depth of 0-10 cm. All samples were categorised as mineral soil with various contents of organic matter and $\mathrm{pH}$ values (Table 3 ). The samples were classified mostly as non-contaminated soil, as the total content of chromium did not exceed its permissible limit for agricultural soil in Poland (Ordinance of the Minister of Environment of Poland 2016). Despite the use of large amounts of Cr(III) compounds in tannery, only two samples from its area ( 3 and 4) were classified as contaminated soil. The content of $\mathrm{Cr}(\mathrm{VI})$ in the samples was assessed by two developed and recommended procedures based on extraction with $0.1 \mathrm{~mol} \mathrm{~L}^{-1} \mathrm{Na}_{2} \mathrm{CO}_{3}$ solution at room and elevated (90$\left.95{ }^{\circ} \mathrm{C}\right)$ temperature. The results did not differ significantly (Table 3 ). The share of $\mathrm{Cr}(\mathrm{VI})$ in the total content of chromium in the analysed soil was very low, i.e. in the range of 0.8 to $4.5 \%$. This low content of extracted $\mathrm{Cr}(\mathrm{VI})$ in the analysed soil, despite the high total content of chromium, indicates that chromium is present in very immobile forms, probably as stable $\mathrm{Cr}$ (III) compounds.

\section{Conclusions}

The procedures proposed in the literature for the extraction of various forms of $\mathrm{Cr}(\mathrm{VI})$ from solid matrices were tested under uniform conditions in order to evaluate their selectivity and efficiency towards $\mathrm{Cr}(\mathrm{VI})$ and $\mathrm{Cr}(\mathrm{III})$ species. None of the tested reagents showed suitable extraction power towards quantitative extraction of $\mathrm{Cr}$ (III) species. The procedures based on $\mathrm{Na}_{2} \mathrm{CO}_{3}$ (at room and elevated temperatures) were found to be suitable for extraction of $\mathrm{Cr}(\mathrm{VI})$ species from mineral soil. The procedure based on extraction of $\mathrm{Cr}(\mathrm{VI})$ with $\mathrm{Na}_{2} \mathrm{CO}_{3}$ solution at room temperature is recommended for organic soil analysis, as partial co-extraction and oxidation of $\mathrm{Cr}$ (III) arises at a higher temperature. The proposed procedures were validated and accuracy was proved by analysis of CRM of soil (CRM 041).

The studies conducted here show that the physical state of waste, initial form and oxidation state of chromium as well as soil properties had an influence on the final form of chromium species in soil, which affected its mobility. It was found that $\mathrm{Cr}$ (III) introduced into soil as a solid waste was immobile, while introduced as a liquid, it may became mobile depending on the environmental conditions. $\mathrm{Cr}(\mathrm{VI})$ compounds disposed in the form of solid waste enter the soil after solubilisation. Compounds of $\mathrm{Cr}(\mathrm{VI})$ disposed as liquid waste undergo various reactions with the soil matrix and their reduction may occur; therefore, data on the sources of pollution and original forms of chromium in wastes are necessary for better prediction and estimation of the presence of chromium species in soil.

The analysis of soil collected from the contaminated area of the old tannery revealed that the share of $\mathrm{Cr}(\mathrm{VI})$ was very low (only $0.8-4.5 \%$ ) despite the high total content of chromium. This confirms that chromium was present in the soil in immobile forms, probably as $\mathrm{Cr}(\mathrm{III})$ compounds.

Table 3 The characteristic of soil samples collected from contaminated area of old leather tannery and the results of $\mathrm{Cr}(\mathrm{VI})$ extraction with $\mathrm{Na}_{2} \mathrm{CO}_{3}$ solution

\begin{tabular}{|c|c|c|c|c|c|c|c|}
\hline \multirow[t]{2}{*}{ Sample } & \multirow[t]{2}{*}{$\mathrm{pH}_{\mathrm{KCl}}$} & \multirow[t]{2}{*}{$\begin{array}{l}\text { Organic } \\
\text { matter, } \%\end{array}$} & \multirow[t]{2}{*}{$\begin{array}{l}\text { Total content of } \\
\mathrm{Cr}, \mu \mathrm{g} \mathrm{g}^{-1}, n=3\end{array}$} & \multicolumn{2}{|c|}{$\begin{array}{l}\text { Extraction with } \mathrm{Na}_{2} \mathrm{CO}_{3} \text { at room } \\
\text { temperature, } n=3\end{array}$} & \multicolumn{2}{|c|}{ Extraction with $\mathrm{Na}_{2} \mathrm{CO}_{3}$ at $90-95^{\circ} \mathrm{C}, n=3$} \\
\hline & & & & $\begin{array}{l}\text { Content of } \\
\mathrm{Cr}(\mathrm{VI}) \pm \mathrm{SD} \\
\mu \mathrm{g} \mathrm{g}^{-1}\end{array}$ & $\begin{array}{l}\text { Percentage of } \mathrm{Cr}(\mathrm{VI}) \text { in } \\
\text { total content } \pm \mathrm{SD}, \%\end{array}$ & $\begin{array}{l}\text { Content of } \\
\mathrm{Cr}(\mathrm{VI}) \pm \mathrm{SD}, \\
\mu \mathrm{g} \mathrm{g}^{-1}\end{array}$ & $\begin{array}{l}\text { Percentage of } \mathrm{Cr}(\mathrm{VI}) \text { in } \\
\text { total content } \pm \mathrm{SD}, \%\end{array}$ \\
\hline Soil 1 & 7.8 & 1.86 & $68.6 \pm 5.0$ & $0.88 \pm 0.03$ & $1.29 \pm 0.05$ & $1.55 \pm 0.06$ & $2.27 \pm 0.08$ \\
\hline Soli 2 & 7.3 & 7.34 & $141.9 \pm 6.1$ & $3.54 \pm 0.02$ & $2.50 \pm 0.02$ & $4.36 \pm 0.05$ & $3.07 \pm 0.03$ \\
\hline Soil 3 & 7.2 & 10.14 & $283.9 \pm 7.9$ & $12.90 \pm 1.43$ & $4.54 \pm 0.50$ & $12.18 \pm 0.83$ & $4.29 \pm 0.29$ \\
\hline Soil 4 & 7.7 & 5.38 & $2336 \pm 30$ & $18.21 \pm 0.50$ & $0.78 \pm 0.02$ & $24.49 \pm 0.73$ & $1.05 \pm 0.03$ \\
\hline Soil 5 & 7.3 & 2.90 & $41.8 \pm 3.2$ & $0.54 \pm 0.06$ & $1.30 \pm 0.14$ & $0.45 \pm 0.01$ & $1.09 \pm 0.03$ \\
\hline Soil 6 & 7.4 & 3.10 & $26.0 \pm 0.9$ & $0.57 \pm 0.05$ & $2.20 \pm 0.18$ & $0.55 \pm 0.02$ & $2.13 \pm 0.08$ \\
\hline Soil 7 & 7.4 & 4.34 & $96.9 \pm 2.8$ & $2.38 \pm 0.15$ & $2.46 \pm 0.16$ & $1.94 \pm 0.08$ & $2.00 \pm 0.08$ \\
\hline
\end{tabular}


Acknowledgements The authors kindly acknowledge financial support from the Polish National Science Centre (DEC-2012/07/ B/ST4/01581).

Open Access This article is distributed under the terms of the Creative Commons Attribution 4.0 International License (http:// creativecommons.org/licenses/by/4.0/), which permits unrestricted use, distribution, and reproduction in any medium, provided you give appropriate credit to the original author(s) and the source, provide a link to the Creative Commons license, and indicate if changes were made.

\section{References}

Apte, A. D., Verma, S., Tare, V., \& Bose, P. (2005). Oxidation of $\mathrm{Cr}$ (III) in tannery sludge to $\mathrm{Cr}(\mathrm{VI})$ : field observations and theoretical assessment. Journal of Hazardous Materials, B121, 215-222.

Avudainayagam, S., Megharaj, M., Owens, G., Kookana, R. S., Chittleborough, D., \& Naidu, R. (2003). Chemistry of chromium in soils with emphasis on tannery waste sites. Reviews of Environmental Contamination and Toxicology, 178, 5391.

Barceloux, D. G. (1999). Chromium. Journal of Toxicology. Clinical Toxicology, 37(2), 173-194.

Béni, Á., Karosi, R., \& Posta, J. (2007). Speciation of hexavalent chromium in waters by liquid-liquid extraction and GFAAS determination. Microchemical Journal, 85, 103-108.

Brose, D. A., \& James, B. R. (2010). Oxidation-reduction transformations of chromium in aerobic soils and the role of electron-shuttling quinones. Environmental Science \& Technology, 44, 9438-9444.

Canadian Council of Ministers of the Environment, Canadian environmental quality guidelines, 2001.

Chellan P., Sadler P.J. (2015). The elements of life and medicines. Philosophical Transactions of the Royal Society A 373, 20140182. doi:10.1098/rsta.2014.0182.

Cheng, H., Zhou, T., Li, Q., Lu, L., \& Lin, C. (2014). Anthropogenic chromium emissions in China from 1990 to 2009. PloS One, 9(2), e87753.

Decreto Ministeriale n.471, Gazetta Ufficiale Supplemento Ordinario N. 293, 1999.

Dhal, B., Thatoi, H. N., Das, N. N., \& Pandey, B. D. (2013). Chemical and microchemical remediation of hexavalent chromium from contaminated soil and mining/metallurgical solid waste: a review. Journal of Hazardous Materials, 250251, 272-291.

Eckert, J. M., Stewart, J. J., Waite, T. D., Szymczak, R., \& Williams, K. L. (1990). Reduction of chromium(VI) at sub$\mu \mathrm{g} 1^{-1}$ levels by fulvic acid. Analytica Chimica Acta, 236, 357-362.

EEA Technical report. (2015). European Union emission inventory report 1990-2013 under the UNECE Convention on Longrange Transboundary Air Pollution (LRTAP) (Vol. 8, p. 69). Luxembourg: Publications Office of the European Union http://www.eea.europa.eu/publications/1rtap-emissioninventory-report/\#parent-fieldname-title; 8.12.2016.
Elci, L., Divrikli, U., Akdogan, A., Hol, A., Cetin, A., \& Soylak, M. (2010). Selective extraction of chromium(VI) using a leaching procedure with sodium carbonate from some plant leaves, soil and sediment samples. Journal of Hazardous Materials, 173, 778-782.

Evaluation of measurement data - guide to the expression of uncertainty in measurement. 2008. JCGM 100

Gitet, H., Subramanian, P. A., Minilu, D., Kiros, T., Hilawie, M., Gebremariam, G., \& Taye, K. (2013). Speciation of chromium in soils near Sheba Leather Industry, Wukro Ethiopia. Talanta, 116, 626-629.

Grabarczyk, M. (2008). Protocol for extraction and determination of $\mathrm{Cr}(\mathrm{VI})$ in solid materials with a high $\mathrm{Cr}(\mathrm{III}) / \mathrm{Cr}(\mathrm{VI})$ ratio using EDDS as a leaching agent for $\mathrm{Cr}(\mathrm{VI})$ and a masking agent for $\mathrm{Cr}(\mathrm{III})$. Electroanalysis, 20, 1857-1862.

Grabarczyk, M., Korolczuk, M., \& Tyszczuk, K. (2006). Extraction and determination of hexavalent chromium in soil samples. Analytical and Bioanalytical Chemistry, 386, 357362.

Huo, D., \& Kingston, H. M. (2000). Correction of species transformations in the analysis of $\mathrm{Cr}(\mathrm{VI})$ in solid environmental samples using speciated isotope dilution mass spectrometry. Analytical Chemistry, 72, 5047-5054.

Huo, D., Lu, Y., \& Kingston, H. M. (1998). Determination and correction of analytical biases and study on chemical mechanisms in the analysis of $\mathrm{Cr}(\mathrm{VI})$ in soil samples using EPA protocols. Environmental Science \& Technology, 32, 34183423.

James, B. R. (2001). Remediation by reduction strategies for chromate contaminated soils. Environmental Geochemistry and Health, 23, 175-179.

James, B. R., Petura, J. C., Vitale, R. J., \& Mussoline, G. R. (1995). Hexavalent chromium extraction from soils: a comparison of five methods. Environmental Science \& Technology, 29, 2377-2381.

Johnson, J., Schewel, L., \& Graedel, T. E. (2006). The contemporary anthropogenic chromium cycle. Environmental Science \& Technology, 40, 7060-7069.

Kimbrough, D. E., Cohen, Y., Winer, A. M., Creelman, L., \& Mahuni, C. (1999). A critical assessment of chromium in the environment. Critical Reviews in Environmental Science and Technology, 29, 1-46.

Korolczuk, M., \& Grabarczyk, M. (2005). Evaluation of ammonia buffer containing EDTA as an extractant for $\mathrm{Cr}(\mathrm{VI})$ from solid samples. Talanta, 66, 1320-1325.

Kotaś, J., \& Stasicka, Z. (2000). Chromium occurrence in the environment and methods of its speciation. Environmental Pollution, 107, 263-283.

Krasnodębska-Ostręga, B., Paldyna, J., Kowalska, J., Jedynak, Ł., \& Golimowski, J. (2009). Fractionation study in bioleached metallurgy wastes using six-step sequential extraction. Journal of Hazardous Materials, 167, 128-135.

Leśniewska, B., Krymska, M., Świerad, E., Wiater, J., \& Godlewska-Żyłkiewicz, B. (2016). An ultrasound-assisted procedure for fast screening of mobile fractions of $\mathrm{Cd}, \mathrm{Pb}$ and $\mathrm{Ni}$ in soil. Insight into method optimization and validation. Environmental Science and Pollution Research, 23, 25093-25104.

Lillengen, B., \& Wibetoe, G. (2002). Graphite furnace atomic absorption spectrometry used for determination of total 
EDTA and acetic acid extractable chromium and cobalt in soils. Analytical and Bioanalytical Chemistry, 372, 187-195.

Malherbe, J., Isaure, M. P., Seby, F., Watson, R. P., RodrigezGonzalez, P., Stutzman, P. E., Davis, C. W., Maurizio, C., Unceta, N., Sieber, J. R., Long, S. E., \& Donard, O. F. X. (2011). Evaluation of hexavalent chromium extraction method EPA method 3060A for soils using XANES spectroscopy. Environmental Science \& Technology, 45, 10492-10500.

Mandiwana, K. L. (2008). Rapid leaching of Cr(VI) in soil with $\mathrm{Na}_{3} \mathrm{PO}_{4}$ in the determination of hexavalent chromium by electrothermal atomic absorption spectrometry. Talanta, 74, 736-740.

Metze, D., Jakubowski, N., \& Klockow, D. (2005). Speciation of chromium in environment and food. In R. Cornelis, H. Crews, J. Caruso, \& K. G. Heumann (Eds.), Handbook of elemental speciation II: species in the environment, food, medicine and occupational health (pp. 120-134). Chichester: Wiley.

Morales-Muñoz, S., Luque-Garcia, J. L., \& Luque de Castro, M. D. (2004). A continuous approach for the determination of $\mathrm{Cr}(\mathrm{VI})$ in sediment and soil based on the coupling of microwave-assisted water extraction, preconcentration, derivatization and photometric detection. Analytica Chimica Acta, 515, 343-348.

Ordinance of the Minister of Environment of Poland concerning manner of conducting the assessment of contamination of the earth surface. Official Journal 2016, p.1395.

Paldyna, J., Krasnodębska-Ostręga, B., Kregielewska, K., Kowalska, J., Jedynak, Ł., Golimowski, J., Grobelski, T., Farbiszewska-Kiczma, J., \& Farbiszewska, T. (2013). The assessment of environmental pollution caused by mining and metallurgy wastes from highly polluted post-industrial regions in Southern Poland. Environment and Earth Science, $68,439-450$.

Panichev, N., Mandiwana, K., \& Foukaridis, G. (2003). Electrothermal atomic absorption spectrometric determination of $\mathrm{Cr}(\mathrm{VI})$ in soil after leaching of $\mathrm{Cr}(\mathrm{VI})$ species with carbon dioxide. Analytica Chimica Acta, 491, 81-89.
Pantsar-Kallio, M., Reinikainen, S. P., \& Oksanen, M. (2001). Interactions of soil components and their effects on speciation of chromium in soils. Analytica Chimica Acta, 439, 9-17.

Pettine, M., \& Capri, S. (2005a). Digestion treatments and risks of $\mathrm{Cr}(\mathrm{III})-\mathrm{Cr}(\mathrm{VI})$ interconversions during $\mathrm{Cr}(\mathrm{VI})$ determination in soils and sediments - a review. Analytica Chimica Acta, 540, 231-238.

Pettine, M., \& Capri, S. (2005b). Removal of humic matter interference in the determination of $\mathrm{Cr}(\mathrm{VI})$ in soil extracts by the diphenylcarbazide method. Analytica Chimica Acta, 540, 239-246.

Rüdel, H., \& Terytze, K. (1999). Determination of extractable chromium(VI) in soils using a photometric method. Chemosphere, 39, 697-708.

Swedish Environmental Protection Agency, Guidelines for polluted soils. 2002 (chapter 2).

Szulczewski, M. D., Helmke, P. A., \& Bleam, W. B. (1997). Comparison of XANES analyses and extractions to determine chromium speciation in contaminated soils. Environmental Science \& Technology, 31, 2954-2959.

Unceta, N., Séby, F., Malherbe, J., \& Donard, O. F. (2010). Chromium speciation in solid matrices and regulation: a review. Analytical and Bioanalytical Chemistry, 397, 10971111.

Vincent, J. B. (2010). Chromium: celebrating 50 years as an essential element? Dalton Transactions, 39, 3787-3794.

Vitale, R. J., Mussoline, G. R., Petura, J. C., \& James, B. R. (1995). Hexavalent chromium quantification in soils: an effective and reliable procedure. American Environmental Laboratory, 7(1), 8-10.

Vitale, R. J., Mussoline, G. R., Petura, J. C., \& James, B. R. (1994). Hexavalent chromium extraction from soils: evaluation of an alkaline digestion method. Journal of Environmental Quality, 23, 1249-1256.

Vitale, R. J., Mussoline, G. R., Rinehimer, K., Petura, J. C., \& James, B. R. (1997). Extraction of sparingly soluble chromate from soils: evaluation of methods and Eh-pH effects. Environmental Science \& Technology, 31, 390-394. 